\title{
ARE THERE ANY DIFFERENCES IN SIMPLE AND RANDOM CHOICE MOTOR TASK PERFORMANCE BETWEEN YOUNG AND MIDDLE-AGED ADULTS?
}

\author{
Rima Solianik', Vaida Aleknavičiūtė ${ }^{2}$, Albertas Skurvydas', Marius Brazaitis ${ }^{1}$ \\ Lithuanian Sports University', Kaunas, Lithuania \\ Šiauliai University ${ }^{2}$, Šiauliai, Lithuania
}

\begin{abstract}
Research background and hypothesis. Most studies are based on elderly subjects' results, so there is a need to explore if motor performance changes begin in the middle age. We hypothesize that (i) middle-aged subjects use "play it safe" strategy, which depends on the type of tasks (simple vs. random choice); (ii) middle-aged subjects will show higher intra-individual performance variability compared to young adults, furthermore, simple task will show lower performance variability.

Research aim was to establish if there were any movement performance differences during simple and random choice motor task performance between young and middle-aged adults.

Research methods. Middle-aged and young adults performed two speed-accuracy tasks. During simple task participants had to reach the same target which appeared in the same place and during random choice task the target appeared randomly in one of the three different places.

Research results. Data showed that middle-aged group had slower $(\mathrm{p}<0.05)$ reaction time and maximal velocity, whereas movement path length was more accurate $(\mathrm{p}<0.05)$ than that in the young adult group. Comparing different tasks it was observed that during simple task reaction time was faster $(\mathrm{p}<0.05)$ than in the random choice task in both groups. Intra-individual variability of reaction time and maximal velocity was higher $(\mathrm{p}<0.05)$ in the middleaged group, whereas no changes were observed between different tasks.

Discussion and conclusion. Motor performance strategy "play it safe" is already observed for the middleaged population: they decrease maximal velocity and reaction time in order to make movement more accurate. Additionally, they demonstrate task-independent higher intra-individual variability of reaction time and maximal velocity showing changes in CNS integrity compared to young adults.
\end{abstract}

Keywords: aging, speed-accuracy tasks, intra-individual variability.

\section{INTRODUCTION}

$\mathrm{C}$ hanges in a number of cognitive and motor tasks are seen as part of the normal aging process in humans. Various neural deficits are related to age including reaction time and attention impairment (Jones et al., 1995; Ward, Frackowiak, 2003; Gorus et al., 2008; Tun, Lachman, 2008), decreased speed of information processing and motor control (Kennedy, Raz, 2005; Gorus et al., 2008; Hueninckx et al., 2008), and increased performance variability (Sosnoff, Newell, 2011; Dykiert et al., 2012). Many of these studies found linear decrease in functional motor and cognitive performance tasks with increasing age.

Psychomotor performance reflects the time a subject takes to react to stimuli (Botwinick, Thompson, 1996). It can be evaluated as reaction time (Punekar, Kelkar, 2006), which is the duration of the interval between presentation of a stimulus and the participant's response to the stimulus (Der, Deary, 2006). Reaction time emphasizes the special place of speed of processing in aging and 
it is a fundamental property of the central nervous system (CNS) (Deary, Der, 2005). Information processing takes longer time and its duration becomes more variable with aging (Deary, Der, 2005; Der, Deary, 2006; Punekar, Kelkar, 2006). Research studies have indicated a slowing rate of simple and disjunctive reaction (Deary, Der, 2005), and the fact that with increasing age simple as well as choice task performance decreases (Punekar, Kelkar, 2006; Hueninckx et al., 2008; Lindberg et al., 2009).

Elderly subjects show poorer motor performance skills due to reduced speed, accuracy, and increased movement variability. The decline in motor skills can be due to neuromuscular, biomechanical and cognitive decline (Seidler et al., 2010; Raw et al., 2012). Older adults' movement time is slower compared to that of young adults. Additionally, for young and old adults time increases linearly as difficulty of task increases (Kennedy, Raz, 2005; Hueninckx et al., 2008). Moreover, age-related movement slowing can be complemented by compensatory processes (Raw et al., 2012). J. Trommershäuser and co-authors (2005) suggest that humans can optimize motor strategies. Elderly subjects can slower actions to make getting feedback easier for movement corrections. Increased movement duration allows performing tasks more accurately (Welsh et al., 2007). Referring to age effect on reduced motor planning abilities (de Jong, 2001) and cognitive flexibility (Wecker et al., 2005), our first hypothesis is that middle-aged subject will use "play it safe" strategy to perform movement successfully and that random choice motor task will be affected more than simple task.

Based on a compensation hypothesis, during the functional task, elderly subjects can activate the same brain regions as younger subjects, but to a larger extent. Furthermore, they can activate additional brain areas (Hueninckx et al., 2008). In this way brain overactivation could emerge, which is frequently observed in prefrontal sites (Dolcos et al., 2002; Cabeza et al., 2004; ReuterLorenz, Cappell, 2008). In elderly adults, brain overactivation is often found in the opposite brain hemisphere regions compared to young adults (Reuter-Lorenz, Cappell, 2008). Studies showed that brain overactivation of elderly subjects increased opportunity to remember facts or sentences during memory performance tasks (Boyed et al., 2008; Wingfield, Grossman, 2006;
Reuter-Lorenz, Cappell, 2008), and improved motor task performance (Hueninckx et al., 2008). We failed to find any evidence if this compensation model was observed in middle aged subjects. Despite that, it is known that increased variability marks changes of CNS functioning, and agerelated higher variability is observed during choice task performance than in the simple task performance (Dykiert et al., 2012). Based on that statement, we pose the second hypothesis that middle-aged subjects will have higher variability compared to young adults, and that random choice task will show higher intra-individual performance variability compared to simple task.

It can be seen that brain may increase function by direct brain activation changes or strategic compensation (Raw et al., 2012). Most studies are based on elderly subjects' results, so there is a need to explore the performance of middle-aged subjects during different tasks, and to identify if age deficits begin in the middle age. It is important to clarify if they use compensatory ("play it safe") strategy or/and brain overactivation in order to keep good motor performance. The aim of this research was to identify if there were differences in simple and random choice movement performance between young and middle-aged adults, and to confirm above mentioned hypothesis, that (i) middle-aged subjects use "play it safe" strategy, which depends on the type of tasks (simple vs. random choice); (ii) middle-aged subjects will show higher intraindividual performance variability compared to young adults, furthermore, simple task will show lower performance variability.

\section{RESEARCH METHODS}

Participants. All participants were righthanded. Hand preference was determined with the "Edinburgh Handedness Inventory" (Oldfield, 1971). Seventy six healthy subjects were divided into two groups by age. The first group consisted of 38 middle-aged participants (19 females and 19 males; mean age (SD) 52.4 (4.6) yr, $1.71(0.8)$ $\mathrm{m}$ height, 80 (11.4) kg mass, BMI 27.2 (2.8)), ant the second group consisted of 38 young adults (20 females and 18 males; mean age (SD) $23.6(2.5) \mathrm{yr}$, $1.76(0.9) \mathrm{m}$ height, 73.8 (15.2) kg body mas, BMI 23.4 (3.1)). All subjects were without neurological symptoms and in good physical condition. The study was approved by the local human research ethics committee and conduced in accordance with the Declaration of Helsinki. Besides, all 
participants provided informed consent before the experiments.

Standardization of the experimental conditions. The initial subjects' visit involved familiarization with experimental procedures and equipment. Familiarization was performed on the analyser of dynamic parameters of human leg and arm movement (DPA-1; Patent No. 5251; 200508 25). Subjects were allowed to try two different reaching tasks 3-5 times. The target was a $0.35 \mathrm{~cm}$ radius red circle and the start zone was a $0.70 \mathrm{~cm}$ radius green circle. The distance from the start zone to the target was $10 \mathrm{~cm}$. During each task the participant was required to position the $0.35 \mathrm{~cm}$ radius handle symbol in the start zone (the centre of a $0.70 \mathrm{~cm}$ radius green circle) on the computer screen. The program intermittently (every $1-3$ s) generated a sound signal and a target in the certain place on the computer screen. The participants were asked and motivated to perform multitask: to react to the target appearing on the computer screen and reach the target as quickly as possible and in the most accurate trajectory. The endpoint of the movement was recorded when the centre of the handle symbol stopped in the circle and stayed there for no less than $0.02 \mathrm{~s}$. After subjects confirmation of the clarity of motor tasks a day later they returned to the laboratory for the experimental procedure.

Before motor task the current level of subjective sleepiness was evaluated using the Stanford Sleepiness Scale (SSS) (Hoddes et al., 1972). The SSS contains seven definitions of different levels of current sleepiness ranging from 1 'feeling active and vital; alert; wide awake' to 7 'almost in reverie; sleep onset soon; lost struggle to remain awake'. The participants had to choose the most appropriate description of their subjective level of sleepiness. Only those participants whose sleepiness level ranged from 1 to 3 were included in the study.

Motor tasks and their measurements. Two speed-accuracy tasks were performed. Motor tasks were performed on the DPA-1. The subject's position had been described in previous studies (Zuoza et al., 2009). The distance between the computer screen and the subject's eyes was approximately $70 \mathrm{~cm}$. A handle was given to the participant's right hand, from which the parameters of hand movements at the distal part of the hand were recorded. The sampling rate was $200 \mathrm{~Hz}$. The handle at the end of the lever was allowed to move only in a horizontal plane. Subjects performed two different goal-directed reaching tasks with dominant hand as fast as possible (Figure). Priority of the tasks was chosen randomly. Subjects had 5 min rest between different tasks. Simple task consisted of 20 goal-directed reaching movements during which participants had to reach the same target which appeared in the same place on the computer screen as fast as possible; and random choice task consisted of 20 reaching movements during which the target appeared randomly in one of the three different places in same distance. The measurement cycle was completed after hitting the target with the circle of the handle symbol. The program registered the reaction time, movement path length, maximal and average velocities.

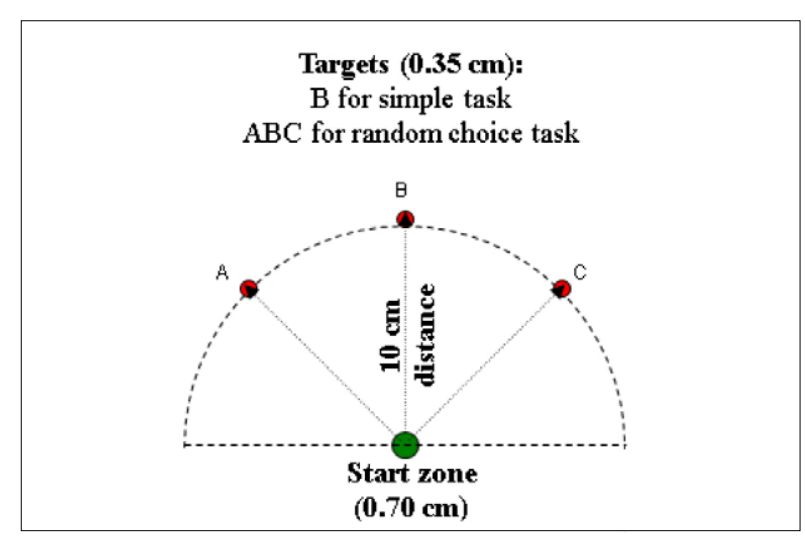

Figure. Illustration of simple and random choice motor tasks

According to P. M. Fitts (1954), a movement task difficulty (ID, the "index of difficulty") can be quantified using information theory metric "bits". Specifically, ID $=\log _{2}(2 \mathrm{~A} / \mathrm{W})$, where $\mathrm{A}$ is the amplitude of movement $(10 \mathrm{~cm})$ and $\mathrm{W}(0.35 \mathrm{~cm})$ is the target width. ID in simple and random choice task was 5.84 bits.

Statistical Analysis. Descriptive data are presented as means \pm standard deviations (SD). The intra-individual variability coefficients of variation (CV) were calculated by applying the following formula: $\mathrm{CV}=(\mathrm{Mean} / \mathrm{SD}) \times 100 \%$. Normality of data distribution was tested and confirmed by the Kolmogorov-Smirnov test. Statistical analysis consisted of two-way analysis of variance (ANOVA) with the between-subjects factor of age (middle aged, young adults) and the within-subjects factor of condition (simple, random choice). Based on alpha level of 0.05 and sample size $(n=76)$, the statistical power (SP) was calculated. 


\section{RESEARCH RESULTS}

Age related differences between simple random choice task performances. Table 1 represents average values of simple and random motor task performance for the young and middleaged groups. In both motor tasks middle-aged group showed slower reaction time $(\mathrm{p}<0.05$; $\mathrm{SP}=1)$ and maximal velocity $(\mathrm{p}<0.05$; $\mathrm{SP}=1)$, whereas movement path length was shorter $(\mathrm{p}<0.05 ; \mathrm{SP}=0.51)$ than in the young adult group.

Comparison of different tasks showed that in both groups reaction time was faster during simple task $(\mathrm{p}<0.01 ; \mathrm{SP}=1)$. Maximal velocity and movement path length did not differ. The Age $\mathrm{x}$ Task interaction did not reach significance level in all variables.

Age related intra-individual variability differences between simple and random choice task performance. Table 2 represents percentage values of simple and random choice motor task performance intra-individual variability for the young and middle-aged groups. Middle-aged group showed higher variability of reaction time $(\mathrm{p}<0.05$; $\mathrm{SP}=1)$ and maximal velocity $(\mathrm{p}<0.05 ; \mathrm{SP}=0.77)$ during both tasks compared to young adults group. Variability of movement path length did not differ. Comparison of different tasks showed that there was no significant difference in both age groups. There was not observed any significant interaction effect between Age x Task.

\section{DISCUSSION}

The aim of the present study was to investigate the dependence of movement parameters on age (young vs. middle aged) and different task (simple vs. random choice). Firstly, we hypothesised that middle-aged subjects use "play it safe" strategy, which is task dependent. Our study confirmed that middle-aged subjects used this strategy, and that reaction time was faster during simple task. Secondly, we hypothesized that middleaged subjects would show higher intra-individual performance variability compared to young adults, and that simple task performance would show lower variability compared to random choice task. Our study confirmed that middle-aged subjects showed higher performance intra-individual variability, however, it did not depend on task type.

Compared to young adults, elderly persons can show longer reaction time and decreased velocity, which can be accompanied with shorter path length (Welsh et al., 2007). We confirm that middleaged subjects used the same strategy for feedback control to correct their programmed actions. They decreased maximal velocity and reaction time in order to make movement more accurate (shorter path length) (Table 1). Additionally, J. Feeney and coauthors (2002) established, that motor performance in the middle-aged subjects was faster and more accurate responding to predictable (simple) than unpredictable (random choice) tasks. It is known
Table 1. Average values of motor task performance between the groups of middle-aged and young adults

Note. MA - middle-aged adults; YA young adults; * - difference statistically significant at 0.05 level as compared with values between different tasks; $\S$ - difference statistically significant at 0.05 level as compared with values between different age groups.

\begin{tabular}{|c|c|c|c|c|c|c|}
\hline \multirow{2}{*}{ 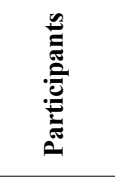 } & \multicolumn{3}{|c|}{ Simple task } & \multicolumn{3}{|c|}{ Random choice task } \\
\hline & $\begin{array}{c}\text { Reaction } \\
\text { time, } s\end{array}$ & $\begin{array}{c}\text { Maximal } \\
\text { velocity, } \mathrm{cm} / \mathrm{s}\end{array}$ & $\begin{array}{c}\text { Movement } \\
\text { path length, } \\
\text { cm }\end{array}$ & $\begin{array}{l}\text { Reaction } \\
\text { time, s }\end{array}$ & $\begin{array}{c}\text { Maximal } \\
\text { velocity, } \mathrm{cm} / \mathrm{s}\end{array}$ & $\begin{array}{c}\text { Movement } \\
\text { path length, } \\
\text { mm }\end{array}$ \\
\hline $\begin{array}{c}\text { YA } \\
(n=38)\end{array}$ & $\begin{array}{l}0.27 * \S \\
\pm 0.0\end{array}$ & $\begin{array}{l}42.45^{\S} \\
\pm 15.8\end{array}$ & $\begin{array}{l}11.18^{\S} \\
\pm 0.7\end{array}$ & $\begin{array}{l}0.32^{\S} \\
\pm 0.0\end{array}$ & $\begin{array}{l}37.33^{\S} \\
\pm 14.7\end{array}$ & $\begin{array}{l}11.31^{\S} \\
\pm 1.0\end{array}$ \\
\hline $\begin{array}{c}\text { MA } \\
(n=38)\end{array}$ & $\begin{array}{l}0.32 * \\
\pm 0.1\end{array}$ & $\begin{array}{l}27.24 \\
\pm 8.7\end{array}$ & $\begin{array}{l}10.86 \\
\pm 0.5\end{array}$ & $\begin{array}{r}0.36 \\
\pm 0.1\end{array}$ & $\begin{array}{c}26.46 \\
\pm 9.1\end{array}$ & $\begin{array}{l}11.10 \\
\pm 0.9\end{array}$ \\
\hline
\end{tabular}

Table 2. Percentage values of motor task performance intra-individual variability between the groups of middle-aged and young adults

Note. MA - middle-aged adults; YA young adults; ${ }^{\S}$ - difference statistically significant at 0.05 level as compared with values between different age groups.

\begin{tabular}{|c|c|c|c|c|c|c|}
\hline \multirow{2}{*}{ 苞 } & \multicolumn{3}{|c|}{ Simple task } & \multicolumn{3}{|c|}{ Random choice task } \\
\hline & $\begin{array}{c}\text { Reaction } \\
\text { time, } \%\end{array}$ & $\begin{array}{c}\text { Maximal } \\
\text { velocity, \% }\end{array}$ & $\begin{array}{c}\text { Movement } \\
\text { path length, } \\
\%\end{array}$ & $\begin{array}{c}\text { Reaction } \\
\text { time, } \%\end{array}$ & $\begin{array}{c}\text { Maximal } \\
\text { velocity, \% }\end{array}$ & $\begin{array}{c}\text { Movement } \\
\text { path length, } \\
\%\end{array}$ \\
\hline $\begin{array}{c}\text { YA } \\
(n=38)\end{array}$ & $\begin{array}{c}12.78^{\S} \\
\pm 4.1\end{array}$ & $\begin{array}{l}15.00^{\S} \\
\pm 4.2\end{array}$ & $\begin{array}{l}9.03 \\
\pm 4.0\end{array}$ & $\begin{array}{l}12.92^{\S} \\
\pm 3.6\end{array}$ & $\begin{array}{c}16.63^{\S} \\
\pm 4.0\end{array}$ & $\begin{array}{l}9.53 \\
\pm 4.3\end{array}$ \\
\hline $\begin{array}{c}\text { MA } \\
(n=38)\end{array}$ & $\begin{array}{l}17.70 \\
\pm 5.7\end{array}$ & $\begin{array}{l}18.80 \\
\pm 9.1\end{array}$ & $\begin{array}{r}8.48 \\
\pm 3.7\end{array}$ & $\begin{array}{l}16.82 \\
\pm 6.1\end{array}$ & $\begin{array}{r}19.63 \\
\pm 11.1\end{array}$ & $\begin{array}{l}9.72 \\
\pm 4.8\end{array}$ \\
\hline
\end{tabular}


that the reaction time shows the motor system efficiency to create the motor plan (Gavazzi et al., 2013); therefore our data showed that complicated random choice task required longer reaction time due to more complicated motor planning. We did not observe any differences in movement path length and maximal velocity between tasks. According to our data, we can confirm that middleaged subjects use "play it safe" strategy, and that reaction time is faster during simple task than in the random choice task.

Movement performance variability serves as a measure for successful goal. It is argued that low variability indicates better performance, whereas high variability indicates poorer performance (Slifkin, Newell, 1998). It is known that aging affects movement performance variability. Additionally, age-related variability is larger in choice compared to simple reaction time tasks (Dykiert et al., 2012). Our data (Table 2) confirmed the data of I. J. Deary and G. Der (2005) which showed that intra-individual variability in reaction time increased steadily from the age of 30 to 60 years. Additionally, D. Dykiert's and co-authors (2012) meta-analysis and systematic review showed that age effects were larger in choice reaction time tasks than in simple reaction tasks, however, we did not observe any differences between the performance of different tasks in both age groups. Moreover, we observed that during both tasks middle-aged group showed higher variability of maximal velocity. Considering our data, we can confirm our second hypothesis partly because we did not observe any differences between tasks; meanwhile intra-individual performance variability was higher in the middle-aged subjects. According to M. Wojtowicz and co-authors (2012), who propose that intra-individual variability reflects fairly stable endogenous factors, such as CNS integrity, we can argue about CNS changes due to middle-age. I. J. Sosnoff and K. M. Newell (2011) observed that increased task performance variability of older adults was due to a decreased ability to adapt to the task.

\section{CONCLUSIONS AND PERSPECTIVES}

Our findings complement research literature with deeper knowledge about motor performance strategies of young and middle-aged population, suggesting that already in the middle-age, subjects use task-dependent (simple vs. random choice) "play it safe" strategy to perform motor tasks. Additionally, they show task-independent higher intra-individual performance variability compared to young adults during both tasks.

For further studies and deeper knowledge of motor function changes in middle-aged adults it is useful to explore brain activity CNS processes during hand movements. Additionally, it would be useful to analyse physiological motor system changes related with aging, such as decline of muscle strength and mass, loss of spinal motor neurons as well as decreased number of motor units (Lindberg et al., 2009). These changes can influence motor task performance.

\section{REFERENCES}

Botwinick, J., Thompson, L. (1996). Component of reaction time in relation to age and sex. The Journal of Genetic Psychology, 102, 170-171.

Boyed, L. A., Vidoni, E. D., Siengsukon, C. F. (2008). Multidimensional motor sequences learning is impaired in older but not younger or middle-aged adults. Physical Therapy, 88 (3), 351-361.

Cabeza, R., Daselaar, S., Dolcos, F. et al. (2004). Taskindependent and task-specific age effects on brain activity during working memory, visual attention, and episodic retrieval. Cerebral Cortex, 14, 364-375.

Deary, I. J., Der, G. (2005). Reaction Time, Age, and Cognitive ability: Longitudinal findings from age 16 to 63 years in representative population samples. Aging Neuropsychology, and Cognition, 12, 187-215.
Der, G., Deary, I. J. (2006). Age and sex differences in reaction time in adulthood: Results from the United Kingdom health and lifestyle survey. Psychology and Aging, 21 (1), 62-73.

Dolcos, F., Rice, J. H., Cabeze, R. (2002). Hemispheric asymmetry and aging: Right hemisphere decline or asymmetry reduction. Neuroscience and Biobehavioral Review, 26, 819-825.

Dykiert, D., Der, G., Starr, J. M., Deary, I. J. (2012). Age differences in intra-individual variability in simple and choice reaction time: Systematic review and metaanalysis. PLoS One, 7 (10), e 45759.

Feeney, J., Howard, J. H., Woward, D. V. (2002). Implicit learning of higher order sequences in middle age. Psychology and Aging, 17 (2), 351-355. 
Fitts, P. M. (1954). The information capacity of the human motor system in controlling the amplitude of movement. Journal of Experimental Psychology, 47, 381-391.

Gavazzi, G., Bisio, A., Pozzo, T. (2013). Time perception of visual motion is tuned by the motor representation of human actions. Scientific Reports, 3, 1168.

Gorus, E., de Raedt, E., Lambert, M., Lemper, J., Mets, T. (2008). Reaction times and performance variability in normal aging, mild cognitive impairment, and Alzheimer's. Journal of Geriatric Psychiatry and Neurology, 21 (3), 204-218.

Hoddes, E., Dement, W., Zarcone, V. (1972). The development and use of the Stanford sleepiness scale. Psychophysiology, 9, 150.

Hueninckx, S., Wenderoth, N., Swinnen, P. (2008). System neuroplasticity in the aging brain: Recruiting additional neural resources for successful motor performance in elderly persons. Journal of Neuroscience, 28 (1), 91-99.

Jones, D. N. C., Barnes, J. C., Kirkby, D. L., Higgins, G. A. (1995). Age-associated impairments in a test of attention: Evidence for involvement of cholinergic systems. Journal of Neuroscience, 15, 11, 7282-7292.

de Jong, R. (2001). Adult age differences in goal activation and goal maintenance. European Journal of Cognitive Psychology, 13, 71-89.

Kennedy, K. M., Raz, N. (2005). Age, sex and regional brain volumes predict perceptual-motor skill acquisition. Cortex. 41, 560-569.

Lindberg, P., Ody, C., Feydy, A., Maier, M. (2009). Precision in isometric precision grip force is reduced in middle-aged adults. Experimental Brain Research, 193 (2), 213-224.

Oldfield, R. C. (1971). The assessment and analysis of handedness: The Edinburgh inventory. Neuropsychologia, 9, 97-113.

Punekar, J. N., Kelkar, R. S. (2006). Psychomotor performance and cognitive abilities in chronic schizophrenics. Indian Journal of Occupational Therapy, 35 (1), 17-21.

Raw, R. K., Kountouriotis, G. K., Mon-Williams, M., Wilkie, R. M. (2012). Movement control in older adults: Does old age mean middle of the road? The Journal of Experimental Psychology: Human Perception and Performance, 38 (3), 735-745.
Reuter-Lorenz, P. A., Cappell, K. A. (2008). Neurocognitive aging and the compensation hypothesis. Current Directions in Psychological Science, 17 (3), 177-182.

Seidler, R. D., Bernard, J. A., Burutolu, T. B. et al. (2010). Motor control and aging: Links to age-related brain structural, functional, and biochemical effects. Neuroscience and Biobehavioral Review, 34 (5), 721-733.

Slifkin, A. B., Newell, K. M. (1998). Is variability in human performance a reflection of system noise? Current Directions in Psychological Science, 7, 170-177.

Sosnoff, J. J., Newell, K. M. (2011). Aging and motor variability: A test of the neural noise hypothesis. Experimental Aging Research, 37 (4), 377-397.

Trommershäuser, J., Gepshtein, S., Maloney, L. T., Landy, M. S., Banks, M. S. (2005). Optimal compensation for changes in task-relevant movement variability. Journal of Neuroscience, 25, 7169-7178.

Tun, P. A., Lachman, M. E. (2008). Age differences in reaction time and attention in a national telephone sample of adults: Education, sex, and task complexity matter. Developmental Psychology, 44 (5), 1421-1429.

Ward, N. S., Frackowiak, R. S. J. (2003). Age-related changes in the neural correlates of motor performance. Brain, 126, 873-888.

Wecker, N. S., Kramer, J. H., Hallam, B. J., Delis, D. C. (2005). Mental flexibility: Age effects on switching. Neuropsychology, 19 (3), 345-352.

Welsh, T. N., Higgins, L., Elliot, D. (2007). Are there age-related differences in learning to optimize speed, accuracy and energy expenditure? Human Movement Science, 26, 892-912.

Wingfield, A., Grossman, M. (2006). Language and the aging brain: Patterns of neural compensation revealed by functional brain imaging. Journal of Neurophysiology, 96 (6), 2830-2839.

Wojtowicz, M., Berrigan, L. I., Fisk, J. D. (2012). Intra-individual variability as a measure of information processing difficulties in multiple sclerosis. Journal of the International Neuropsychological Society, 14 (2), 77-83.

Zuoza, A., Skurvydas, A., Mickeviciene, D. et al. (2009). Behavior of dominant and non-dominant hands during ballistic protractive target-directed movements. Fiziologiia Cheloveka, 35 (5), 62-70. 


\title{
AR JAUNI IR VIDUTINIO AMŽIAUS SUAUGUSIEJI PAPRASTAS BEI SUDĖTINGAS MOTORINES UŽDUOTIS ATLIEKA SKIRTINGAI?
}

\author{
Rima Solianik ${ }^{1}$, Vaida Aleknavičiūtė², Albertas Skurvydas ${ }^{1}$, Marius Brazaitis ${ }^{1}$ \\ Lietuvos sporto universitetas ${ }^{l}$, Kaunas, Lietuva \\ Šiauliu universitetas ${ }^{2}$, Šiauliai, Lietuva
}

\begin{abstract}
SANTRAUKA
Tyrimo pagrindimas ir hipotezė. Dauguma tyrimų yra pagristi vyresniojo amžiaus tiriamujų rezultatais ir trūksta duomenu̧, ar skiriasi judesių atlikimas vidutinio amžiaus tarpsniu. Manome, kad: (i) vidutinio amžiaus tiriamieji naudoja saugumo strategija, kuri priklauso nuo užduoties sudètingumo; bus nustatytas didesnis (ii) vidutinio amžiaus asmenu užduočiu atlikimo kaitumas, lyginant su jaunais suaugusiais tiriamaisiais, be to, jų paprastos užduoties atlikimo kaitumas bus mažesnis.

Tikslas - nustatyti, ar jauni ir vidutinio amžiaus suaugusieji paprastas ir sudètingas motorines užduotis atlieka skirtingai.

Metodai. Vidutinio amžiaus ir jauni suaugusieji atliko dvi greitas ir tikslias užduotis. Paprastos užduoties metu tiriamieji turèjo pasiekti taikini, kuris atsirasdavo toje pačioje vietoje, o atliekant sudètingą užduotị taikinys atsitiktinai atsirasdavo vienoje iš trijų vietu.

Rezultatai. Nustatyta, kad vidutinio amžiaus tiriamujų reakcijos laikas ir maksimalusis greitis buvo mažesnis $(\mathrm{p}<0,05)$, o judesio trajektorija tikslesnè $(\mathrm{p}<0,05)$ nei jaunų suaugusiuju. Lyginant skirtingas užduotis nustatyta, kad abiejų amžiaus grupių tiriamujų paprastos užduoties reakcijos laikas buvo didesnis $(\mathrm{p}<0,05)$ nei sudètingos. Reakcijos laiko ir maksimaliojo greičio kaitumas buvo didesnis $(\mathrm{p}<0,05)$ tarp vidutinio amžiaus asmenu, tuo tarpu skirtingų užduočių atlikimo kaitumas nesiskyrè.

Aptarimas ir išvados. Judesių atlikimo saugumo strategija pastebima jau vidutinio amžiaus tarpsniu: mažinant judesio maksimaluji greitị ir reakcijos laiką atliekamas tikslesnis judesys. Be to, tarp vidutinio amžiaus tiriamujų, nepriklausomai nuo užduoties, pastebėtas didesnis reakcijos laiko ir maksimaliojo greičio kaitumas, kuris rodo centrinès nervu sistemos pokyčius.
\end{abstract}

Raktažodžiai: senèjimas, greitos ir tikslios užduotys, kaitumas.

Gauta 2013 m. rugpjūčio 9 d.

Received on 9 August, 2013

Priimta 2013 m. rugsèjo $9 \mathrm{~d}$.

Accepted on 9 September, 2013

Corresponding author Rima Solianik

Lithuanian Sports University

Sporto str. 6, LT-44221 Kaunas

Lithuania

Tel +37060695214

E-mail rima.solianik@1su.lt 